\title{
TECTONOPHYSICAL INTERPRETATION OF EARTHQUAKE FOCAL MECHANISMS OF THE ZAGROS SYSTEM
}

\author{
Y. M. Volfman, O. B. Gintov, E. Ya. Kolesnikova, A. V. Murovskaya \\ S.I. Subbotin Institute of Geophysics, NAS of Ukraine, Kiev, Ukraine
}

\begin{abstract}
Structural-paragenetic and kinematic methods of tectonophysics are applied to study earthquake focal mechanisms of the Zagros system. Nodal planes of focal mechanisms are identified as $L$-, $L^{\prime}$ - and $R$-, $R^{\prime}$-shears by the first method, whereby coordinates of principal stress axes P, T and $N$ (i.e. in tectonophysics, $\sigma_{1}, \sigma_{3}$ and $\sigma_{2}$, if $\sigma_{1} \geq \sigma_{2} \geq \sigma_{3}$ ) are defined. 'Working' nodal planes corresponding to activated ruptures are revealed. Axes of the main normal stresses are combined into local groups on the basis of the kinematic identity of planes of seismogenic ruptures (Figure 2). The second method is applied to construct stereograms of the main axes $\mathrm{P}, \mathrm{T}$ and $\mathrm{N}$, to construct and interpret stereograms of vectors of seismogenic shifts (Figure 3), and to more clearly define coordinates of principal axes $\sigma_{1}, \sigma_{3}$ и $\sigma_{2}$. As evidenced by their comparison, coordinates of the principal axes obtained by the two tectonophysical methods are well coincident (see Figure 2). Five groups of seismogenesis are distinguished; they differ in combination of deformation regimes and kinematic conditions. Locations are determined of the areas wherein earthquake foci of similar parameters are located. This means that seismogenic zones are distinguished; structural and kinematic characteristics of such zones are determined by parameters of stereographic models of corresponding types of seismogenesis (Figures 4 and 5). It is established that the region is dominated by shear and upthrust deformation regimes due to regional submeridional compression and SW-NE compression (see Figures 4 and 5). Submeridional subhorizontal compression is explained by the northward movement of the Arabian plate, and SW-NE compression is explained by divergent processes within the limits of the Red Sea rift. The time pattern of the seismogenic processes from 1979 to 2001 shows that submeridional compression and SW-NE compression are associated with different deep mechanisms. Processes of SE-NW compression, which are observed in the northern part of the Arabian plate, are caused by its interaction with the Eastern Black Sea microplate.
\end{abstract}

Key words: earthquake focal mechanisms, deformation regime, seismogenic zone, tectonophysical method of structural paragenesises, kinematic method, stress axis.

Recommended by V.S. Imaev

Citation: Volfman Y.M., Gintov O.B., Kolesnikova E.Ya., Murovskaya A.V. 2014. Tectonophysical interpretation of earthquake focal mechanisms of the Zagros system. Geodynamics \& Tectonophysics 5 (1), 305-319. doi: 10.5800/GT-2014-5-1-0129.

\section{ТЕКТОНОФИЗИЧЕСКАЯ ИНТЕРПРЕТАЦИЯ МЕХАНИЗМОВ ОЧАГОВ ЗЕМЛЕТРЯСЕНИЙ СИСТЕМЫ ЗАГРОС}

\author{
Ю. М. Вольфман, О. Б. Гинтов, Е. Я. Колесникова, А. В. Муровская
}

Институт геофизики им. С.И. Субботина НАН Украины, Киев, Украина

Аннотация: При интерпретации механизмов очагов землетрясений системы Загрос применены структурно-парагенетический и кинематический методы тектонофизики. Первым методом нодальные плоскости механизмов очагов идентифицированы как $L-, L^{\prime}-$ и $R$-, $R^{\prime}$-сколы, на основании чего уточнены координаты главных осей напряжений Р, $\mathrm{T}$ и N (в тектонофизике $\sigma_{1}, \sigma_{3}$ и $\sigma_{2}$, при $\sigma_{1} \geq \sigma_{2} \geq \sigma_{3}$ ). Определены «рабочие» нодальные плоскости, соответствующие реальным разрывам. Оси главных нормальных напряжений объединены в локальные группы по признаку кинематической идентичности плоскостей сейсмогенных разрывов (рис. 2). Вторым методом построены стереограммы рас- 
пределения главных осей $\mathrm{P}, \mathrm{T}$ и $\mathrm{N}$, построены и проинтерпретированы стереограммы векторов сейсмогенных подвижек (рис. 3) и уточнены координаты главных осей напряжений. Сопоставление координат главных осей, полученных двумя тектонофизическими методами, показало их хорошую сходимость (рис. 2). Обосновано пять типов сейсмогенеза, характеризуемых разными комбинаторными сочетаниями деформационных режимов и кинематических обстановок; локализованы участки размещения очагов со сходными параметрами, то есть выделены сейсмогенные зоны, структурно-кинематическая характеристика которых определяется параметрами стереографических моделей соответствующих типов сейсмогенеза (рис. 4, 5). Установлено, что доминирующими в регионе являются сдвиговый и взбросовый деформационные режимы, обусловленные обстановками субмеридионального и ЮЗ-СВ регионального сжатия (рис. 4, 5). Субмеридиональное субгоризонтальное сжатие объясняется движением Аравийской плиты на север, а ЮЗ-СВ сжатие - дивергентными процессами в пределах Красноморского рифта. Временная развертка сейсмогенных процессов за 1979-2001 гг. показывает, что субмеридиональное и ЮЗ-СВ сжатие связано с разными глубинными механизмами. Процессы ЮВ-СЗ сжатия, фиксируемые в северной части Аравийской плиты, обусловлены ее взаимодействием с Восточно-Черноморской микроплитой.

Ключевые слова: механизмы очагов землетрясений, деформационный режим, сейсмогенная зона, тектонофизический метод структурных парагенезисов, кинематический метод, оси напряжений.

\section{1. ВВЕДЕНИЕ}

Тектонофизическую интерпретацию подвижек по плоскостям сейсмогенных разрывов для мелкофокусных землетрясений впервые предложил Д. Маккензи [McKenzie, 1969]. Им же был сформулирован ряд принципов определения ориентировок главных осей нормальных напряжений по результатам полевого изучения сейсмогенных зон. Необходимость такой интерпретации была вызвана тем, что в близповерхностных условиях сейсмогенный разлом, как правило, представляет собой систему разноориентированных плоскостей более мелких разрывов, объединяемых общей причиной - разрядкой поля напряжений, накопленных в зоне землетрясения. Аналогичные принципы положены в основу кинематического метода тектонофизики (KMT), разработанного О.И. Гущенко [Gushchenko, 1973, 1979], которым предложена система построения стереограмм векторов подвижек по зеркалам скольжения, а также механизмов очагов землетрясений, определяемых по методике А.В. Введенской [Vvedenskaya, 1969]. Удобство такой системы заключается в том, что на одной стереограмме может быть изображено большое число механизмов очагов без потери информации о нодальных плоскостях и ориентировке осей напряжений. Это, в свою очередь, предопределяет возможность дифференциации очагов землетрясений по сходству параметров полученных решений их механизмов. В дальнейшем методика была усовершенствована Ю.Л. Ребецким, предложившим метод катакластического анализа сейсмогенных разрывных нарушений [Rebetsky, 2003] и вплотную приблизившимся к возможности расчета всех компонент полного тензора напряжений [Rebetsky, 2005] применительно к сейсмически активным регионам. Использование КМТ облегчается созданием целого ряда компьютерных программ, почти полностью автоматизи- рующих процесс обработки и интерпретации (в данной работе использована программа Win TENSOR [Delvaux, Sperner, 2003]).

Теория прочности Кулона-Мора, лежащая в основе построения механизмов очагов по методике А.В. Введенской, является базовой и для другого полевого тектонофизического метода - структурно-парагенетического (СПМТ), которым исследуется внутренняя структура разрывных зон, в том числе сейсмогенных.

Таким образом, методы полевой тектонофизики и сейсмологии обрели общую точку соприкосновения, позволяющую выполнять тектонофизическую интерпретацию решений механизмов очагов землетрясений для сейсмотектонических и геодинамических реконструкций.

Близкие результаты при решении таких задач, в частности по определению направлений главных осей нормальных напряжений, дают и методы статистического анализа фокальных механизмов, обобщенные в работе С.Л. Юнга [Yunga, 1996] и примененные им для исследования геодинамических процессов в складчатых поясах Северной Евразии. Но авторам данной статьи, паралельно ведущим как сейсмологические, так и полевые исследования тектонических деформаций в пределах Украины, кажется более интересным именно тектонофизический подход, так как классификация деформационных режимов земной коры в тектонофизике разработана более детально, а изображение результатов исследований в таком подходе более близко к пониманию геологами.

\section{2. ЦЕЛЬ И ОБЪЕКТ РАБОТЫ}

Целью настоящей работы является тектонофизическая интерпретация сейсмологических данных на статистически представительном материале - решениях 


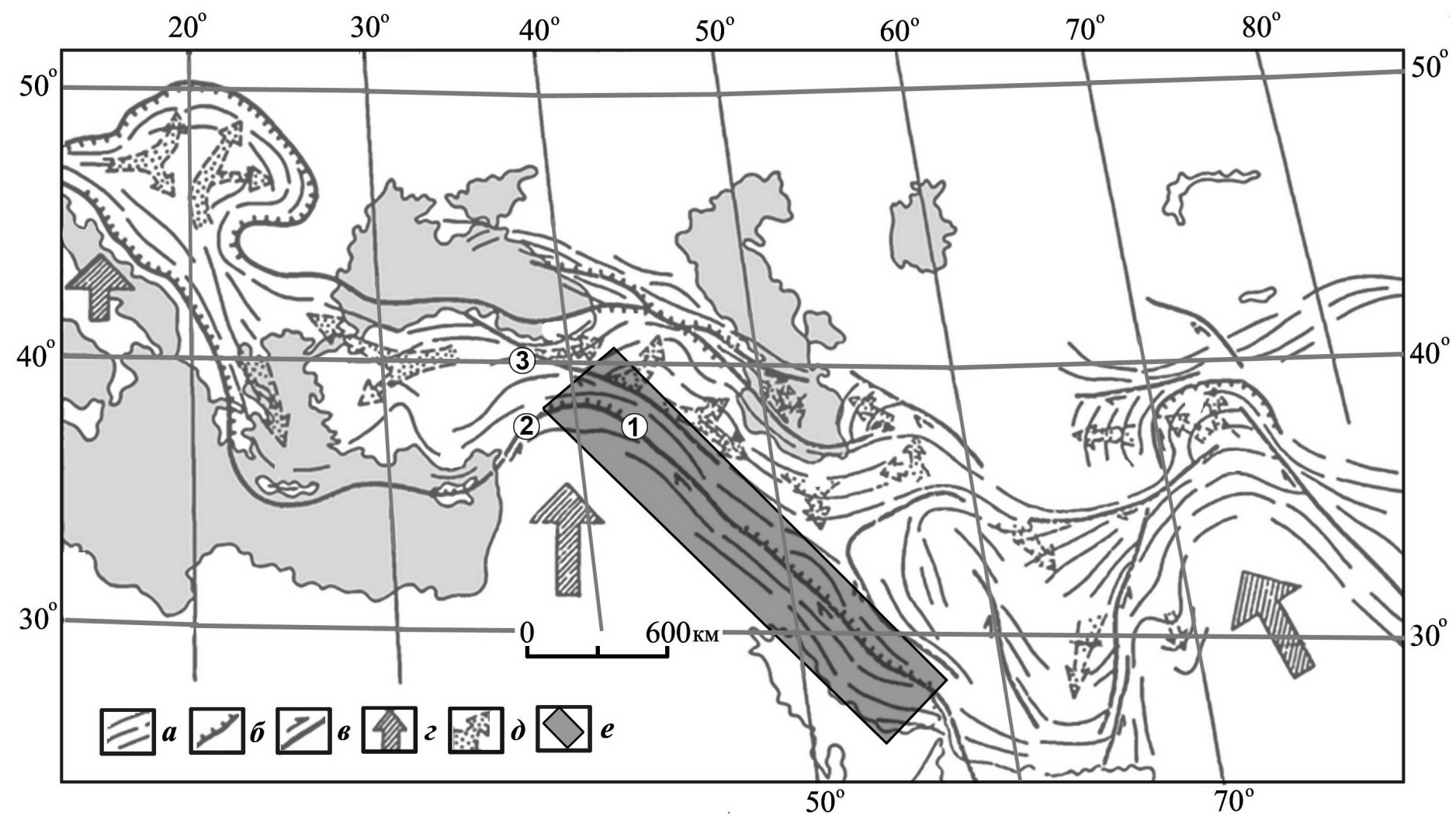

Рис. 1. Положение системы Загрос в структуре Альпийско-Гималайского складчатого пояса (структурная основа - по [Ваzhenov, Burtman, 1990]): a - простирание складок; б - надвиги, фронт шарьяжей; в - сдвиги; г - движение литосферных плит относительно Евразии в новейшее время; $\partial$ - главные тектонические течения в новейшее время; $e$ - исследуемый регион (система Загроса).

Цифры в кружках - зоны региональных разломов: 1 - Загроса, 2 - Анатолийского, 3 - Северо-Анатолийского.

Fig. 1. The position of the Zagros system in the structure of the Alpine-Himalayan folded belt [Bazhenov, Burtman, 1990]: $a-$ strike of folds; $\sigma$ - thrusts, overthrust fronts; 8 - shear faults; 2 - recent movement of the lithospheric plates against Eurasia; $\partial-$ region under study (Zagros system).

Numbers in circles show zones of regional faults: 1 - Zagros, 2 - Anatolian, 3 - North Anatolian.

механизмов очагов землетрясений системы Загрос. Выбор объекта исследований предопределен следующими его особенностями:

- Система является геоструктурным выражением зоны конвергенции Аравийской плиты и окраины Евразии; в современной геодинамической трактовке она позиционируется как северо-восточный фланг Аравийского Синтаксиса протяженностью более 2 тыс. км, что позволяет отнести ее к разряду геоструктур планетарного масштаба (рис. 1).

- Несомненно влияние этой системы на геодинамические особенности Восточно- и Западно-Черноморской микроплит и Крымского полуострова, которые являются главными объектами интересов авторов статьи.

- Протягиваясь в северо-западном направлении от Оманского залива до центральной части Восточной Турции, система Загрос образует тектонический узел с Восточно-Анатолийским и Северо-Анатолийским раз- ломами (вершина Синтаксиса) [Bazhenov, Burtman, 1990; Khain, 2001; и дp.]. Структурная выраженность системы позволяет четко ограничить ее площадь и обеспечить тем самым формирование адекватной выборки данных по механизмам очагов землетрясений. При этом объем выборки является вполне репрезентативным для изучения особенностей сейсмогенеза региона.

\section{3. ИСХОДНЫЕ ДАННЫЕ И СПОСОБЫ ИХ ИНТЕРПРЕТАЦИИ}

Фактологической основой исследований послужили решения механизмов очагов землетрясений, заимствованные из сейсмологического каталога Гарвардского университета (США) за 1977-2001 гг. (http://globalcmt.org/CMTsearch.html) и на сайте Геофизической службы РАН (http://www.ceme.gsras.ru//cgibin/info_quake.pl) для области $25-40^{\circ}$ с. ш. и 40-60 


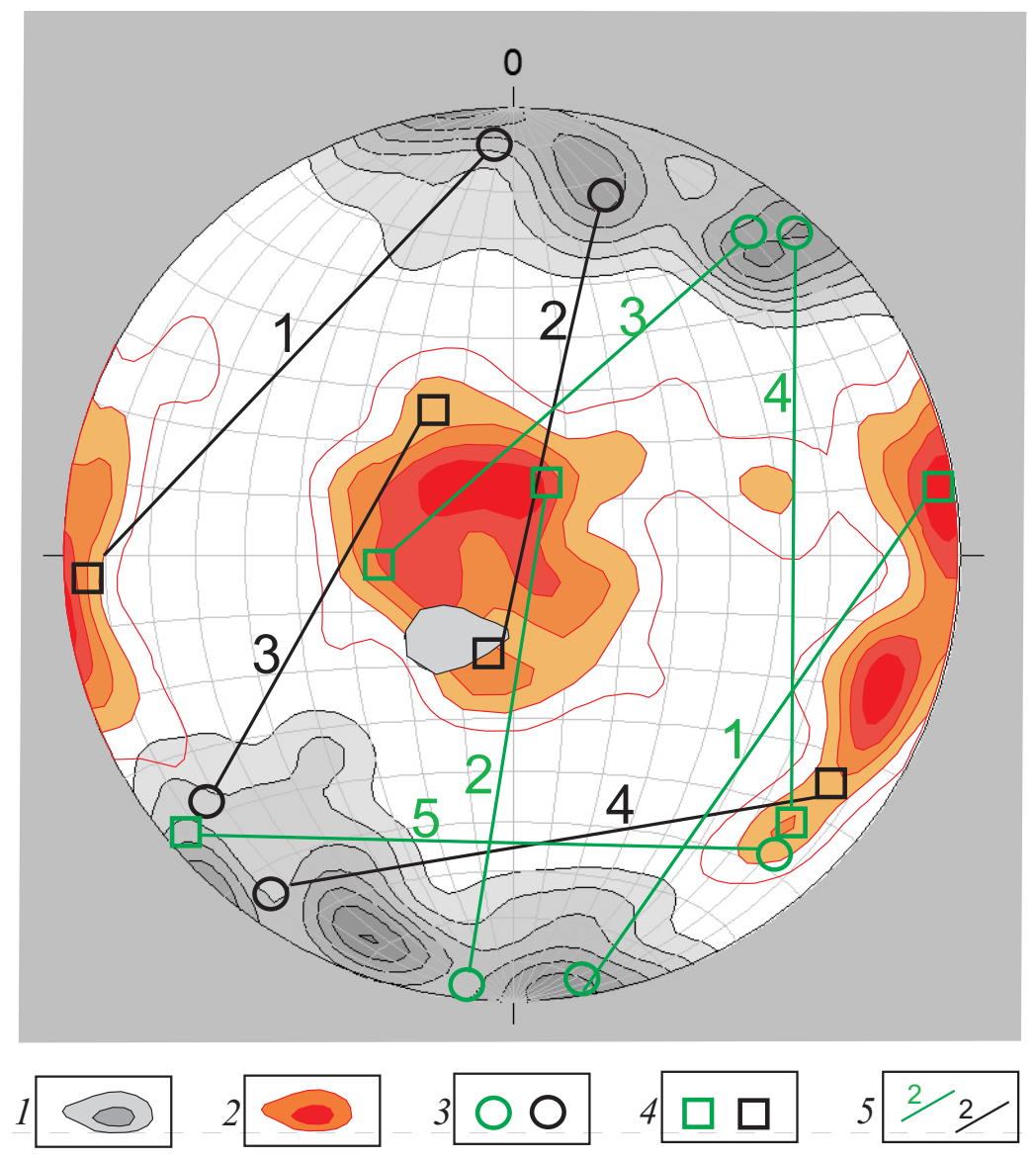

Рис. 2. Стереограмма (нижняя полусфера) проекций осей сжатия (Р) и растяжения (Т) по сейсмологическим данным (100 механизмов очагов).

1, 2 - изолинии концентрации осей Р (1) и Т (2). Результаты тектонофизической интерпретации методом структурных парагенезисов (зеленое) и с помощью программы Win TENSOR (черное): 3 - оси сжатия $\left(\sigma_{1}\right), 4$ - оси растяжения $\left(\sigma_{3}\right), 5$ - линии, соединяющие парные оси $\sigma_{1}$ и $\sigma_{3}$, и номера типов сейсмогенеза, показанных на рис. 4, 5, 7.

Fig. 2. The stereogram (lower hemisphere) showing projections of compression (P) and extension (T) axes from seismological data (100 foci mechanisms).

1, 2 - concentration isolines of axes P (1) and T (2). Results of tectonophysical interpretation by the method of structural paragenesises (green) and Win TENSOR software (black): 3 - compression axes $\left(\sigma_{1}\right), 4$ - extension axes $\left(\sigma_{3}\right), 5$ - connection lines between couple axes $\sigma_{1}$ and $\sigma_{3}$, and numbers of seismogenesis types shown in Figures 4, 5, and 7.

в. д. На этой территории система Загрос выражена линейной зоной относительно обособленного скопления очагов землетрясений. Полученная выборка насчитывает 100 решений механизмов преимущественно коровых очагов с $M>4.0$.

Дифференциация очагов по типам деформационных режимов осуществлялась в соответствии с классификацией, предложенной в работе [Gushchenko et al., 1991]. Она основана на принятых в тектонофизике параметрах - углах наклона $\gamma^{1}, \gamma^{2}$ и $\gamma^{3}$ главных осей нормальных напряжений $\sigma_{1}, \sigma_{2}$ и $\sigma_{3}{ }^{1}$ (в решениях механизмов очагов землетрясений - соответственно, $\mathrm{P}, \mathrm{N}$ и Т) к горизонту.

\footnotetext{
${ }^{1}$ Сжатие принято положительным при $\sigma_{1}>\sigma_{2}>\sigma_{3}$. Углы наклона осей к горизонту, соответственно, $\gamma^{1}, \gamma^{2}$ и $\gamma^{3}$.
}

На стереограмме (рис. 2) механизмы очагов, характеризуемые однотипными деформационными режимами и проекциями осей $\mathrm{P}$ и Т, образуют обособленные скопления в пределах весьма ограниченных сегментов. Эти совокупности анализировались на предмет географического расположения очагов и соответствия осей сжатия и растяжения конкретному землетрясению, что позволило сформировать (на качественном уровне) квазиоднородные выборки механизмов землетрясений по типу деформационного режима и локализации очагов в определенных структурах. Позиции этих совокупностей во многих случаях настолько различаются, что могут рассматриваться как проявления разных условий сейсмогенеза. Это позволило осуществить реконструкцию и идентификацию кинематических обстановок сейсмогенного разрывообразо- 
вания. Помимо типа деформационного режима определялся тип сдвига, ориентировка главных осей сжатия или растяжения и рабочая ось, то есть какая «тектоническая сила» - сжатие или растяжение - являлась первичной. Очаги, имеющие близкие параметры, были объединены в группы, рассматриваемые в качестве стереографической модели определенного типа сейсмогенеза, а в случае закономерного или компактного расположения этих очагов - в качестве модели сейсмогенной или очаговой зоны.

Особенность этой процедуры заключалась в анализе сейсмологических данных с позиций СПМТ. Поскольку сейсмологическое решение механизма очага и тектонофизическое решение обратной задачи по реконструкции условий разрывообразования характеризуют одно и то же явление - быстрое хрупкое разрушение горного массива, такой подход представляется вполне допустимым. Это допущение обусловлено исходными сейсмологическими данными и параметрами решения механизма очага землетрясения, получаемыми в процессе исследования напряжений и разрывов в очагах [Vvedenskaya, 1969]. В таких решениях априори заложена структурно-кинематическая идентификация сейсмогенных разрывов, отвечающих положению нодальных плоскостей: они соответствуют $L$ - и $L^{\prime}$-сколам тектонофизической модели, совпадающим с плоскостями максимальных касательных напряжений. Следовательно, и само решение будет отражать реальную ситуацию лишь при условии, что разрывы в очаге представлены $L$ - и $L^{\prime}$-сколами.

Однако экспериментально установлено и подтверждено полевыми тектонофизическими исследованиями [Stoyanov, 1977; Sherman et al., 1988; Gintov, 2005; Novik, Volfman, 1997; Murovskaya, 2012; и др.], что деформирование горного массива происходит либо посредством образования сопряженных систем $L-$-, $L^{\prime}$-, $R$-, $R^{\prime}$-сколов и трещин отрыва, составляющих единый структурный парагенезис, либо активизацией подвижек по уже существующим разломам. Поскольку в процессе деформирования реализуются, как правило, не все вышеперечисленные типы разрывов, а только некоторые из них (например, сколы Риделя) или их комбинации, весьма вероятно, что и в механизме очага одна из нодальных плоскостей соответствует активному разрыву типа $R$-скола, как первоочередному и наиболее распространенному элементу структурного парагенезиса. В таком случае в окончательное решение механизма очага могут быть внесены коррективы. Допустив, что сейсмогенные разрывы в очагах с близкими параметрами могли реализоваться по типу как $L$ сколов, так и $R$-сколов, подобные очаги можно объединить в один структурно-кинематический парагенезис. Он характеризует сейсмогенную зону как совокупность сколов названных типов, сформированных в едином поле тектонических напряжений. Величины углов скалывания полученных систем $\left(\alpha=25-35^{\circ}\right)$ вполне согласуются с результатами экспериментов, моделирующих условно-мгновенное разрушение осадочных и магматических образований. Таким образом, подход к сейсмотектоническому анализу системы Загрос с позиций СПМТ позволил построить схемы ориентации главных осей региональных полей напряжений и тектонических сил, действовавших в системе Загрос в период с 1979 по 2001 г., и гипотетически связать с этими силами всю позднеальпийскую историю ее развития.

Данные каталогов обработаны также KMT с помощью программы Win TENSOR, что дало возможность сопоставить два независимых способа тектонофизической интерпретации. Были построены и проинтерпретированы стереограммы векторов подвижек и главных осей региональных полей напряжений по 88 землетрясениям (рис. 3). В исходные данные программы Win TENSOR по каждому механизму включались обе нодальные плоскости без выделения плоскости реального разрыва, поэтому на стереограммах (рис. 3) количество векторов подвижек вдвое больше, чем обработанных механизмов.

Полученные ориентировки главных осей напряжений в основном согласуются между собой в обоих подходах (см. рис. 2). При некоторых расхождениях результатов интерпретации предпочтение было отдано первому подходу как менее формальному, позволяющему производить дифференциацию и анализ данных с учетом геологических и географических факторов.

\section{4. ОБЩАЯ ХАРАКТЕРИСТИКА СЕЙСМОТЕКТОНИЧЕСКИХ УСЛОВИЙ}

Анализ решений механизмов очагов землетрясений, локализованных в пределах Загроса, указывает на преобладание очагов, возникших в условиях субмеридионального и ЮЗ-СВ сжатия. По данным СПМТ, с субмеридиональным сжатием связаны 58 \% очагов. При этом проявились преимущественно сдвиговый (25\%), взбросо- (4 \%) и сбросо- (2 \%) сдвиговый, а также взбросовый (27 \%) деформационные режимы сейсмогенеза. Вторая группа очагов (35 \% от общего количества) указывает на наличие обстановок ЮЗ-СВ сжатия. Возникновение сейсмогенных разрывов в очагах этих землетрясений происходило главным образом в условиях взбросового (20 \%), сдвигового (9 \%), взбрососдвигового (4 \%) и сбросо-взбросового (2 \%) деформационных режимов [Volfman, 2013]. Интерпретация по программе Win TENSOR дает практически равное количественное соотношение обстановок субмеридионального и ЮЗ-СВ сжатия: 45 и 43 \%. Расхождение соотношений по двум методам обусловлено разным количеством использованных решений механизмов.

Группа очагов достаточно сильных землетрясений (4 \%) отражает условия ЮВ-СЗ сжатия и сдвигового деформационного режима. На нее обращено внимание потому, что очаги локализованы в пределах системы 

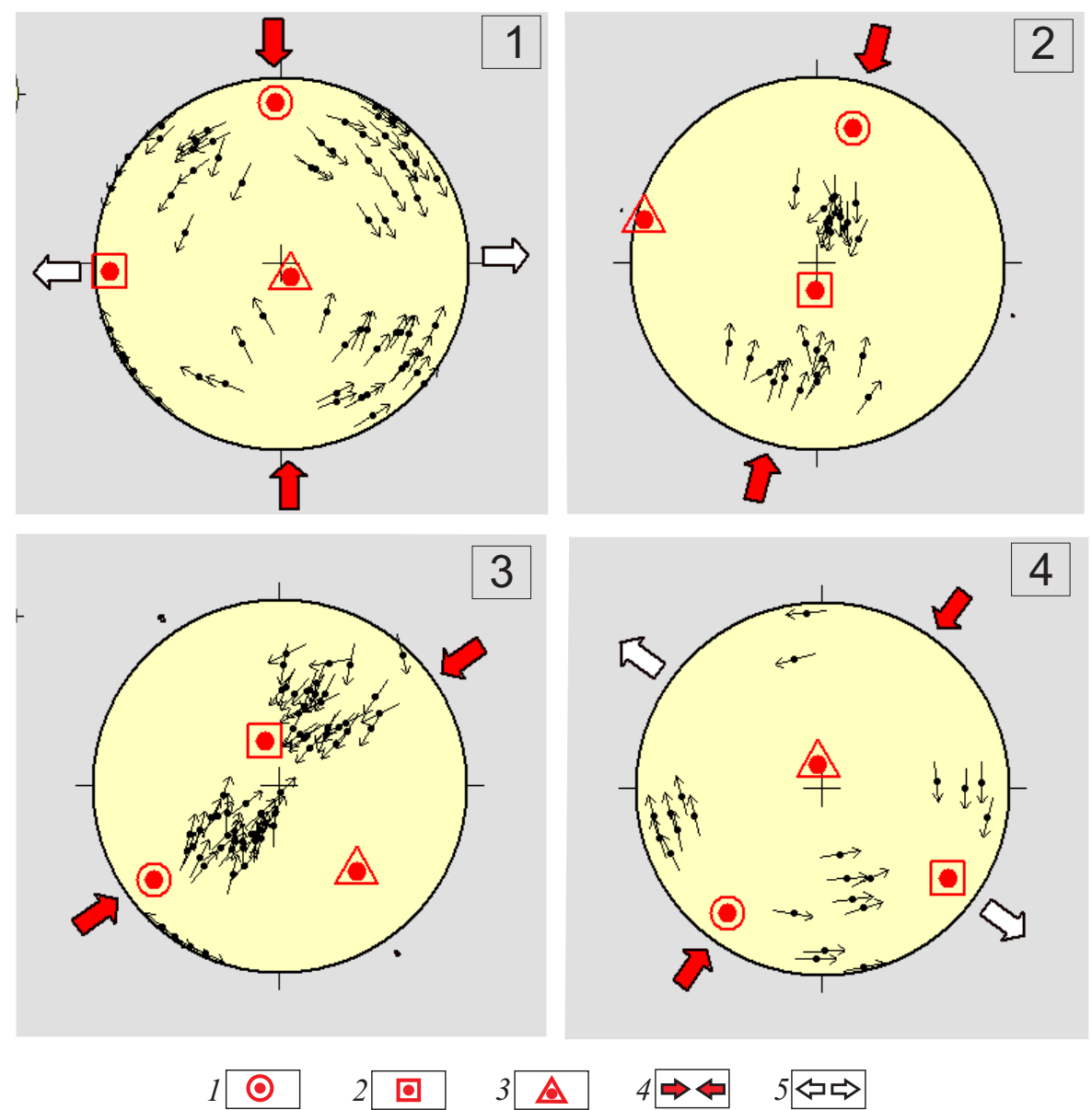

Рис. 3. Стереограммы векторов подвижек и осей напряжений 1-4-го типов сейсмогенеза (номера типов указаны в правых верхних углах), построенные с помощью программы Win TENSOR.

Оси напряжений: $1-\sigma_{1}, 2-\sigma_{3}, 3-\sigma_{2} ; 4$ - генеральное направление сжатия; 5 - генеральное направление растяжения. Относительное количество (\% от 100 механизмов) векторов подвижек, отражающих типы сейсмогенеза: 1-й - 32, 2-й - 13, 3-й - 32, 4-й - 11.

Fig. 3. Stereograms of displacement vectors and stress axes of seismogenesis types 1 to 4 (type numbers are shown in top right corners) as per Win TENSOR.

Stress axes: $1-\sigma_{1}, 2-\sigma_{3}, 3-\sigma_{2} ; 4$ - general strike of compression; 5 - general strike of extension. Relative number (percentage from 100 mechanisms) of displacement vectors that reflect types of seismogenesis: Type $1-32$, Type $2-13$, Type $3-32$, and Type -11 .

широтных разломов, продолжающих на востоке Северо-Анатолийскую зону правого сдвига, и с некоторыми из них связаны катастрофические землетрясения.

Небольшое количество (4 \%) очагов землетрясений (часть из которых имели разрушительные последствия) отражает условия растяжения, а также субширотного сжатия (3 \%). Эти очаги распределены на всей территории хаотически и представляют собой, скорее всего, локальные тектонические подвижки, поэтому детально не анализировались.

Очаги землетрясений, отражающие разные обстановки сейсмогенеза, в пределах изучаемой территории распределены группами, и в большинстве случаев представилось возможным локализовать участки размещения очагов, характеризуемых однотипными параметрами, то есть выделить сейсмогенные зоны, структурно-кинематическая характеристика которых определяется параметрами соответствующих стереографических моделей типов сейсмогенеза (рис. $4,5)$.

Большинство имеющихся решений механизмов очагов отражает наличие пяти типов сейсмогенеза, которые формируют сейсмотектонический климат региона:

Субмеридиональное субгоризонтальное сжатие:

1-й тип: СПМТ - 31 очаг; деформационные режимы - сдвиговый, взбросо- и сбросо-сдвиговый (см. рис. 4); КМТ - 19 очагов; деформационные режимы - сдвиговый, взбросо-сдвиговый;

2-й тип: СПМТ - 27 очагов; деформационный режим - взбросовый (см. рис. 4); КМТ - 10 очагов; деформационный режим - взбросовый.

ЮЗ-СВ субгоризонтальное сжатие:

3-й тип: СПМТ - 22 очага; деформационный режим 


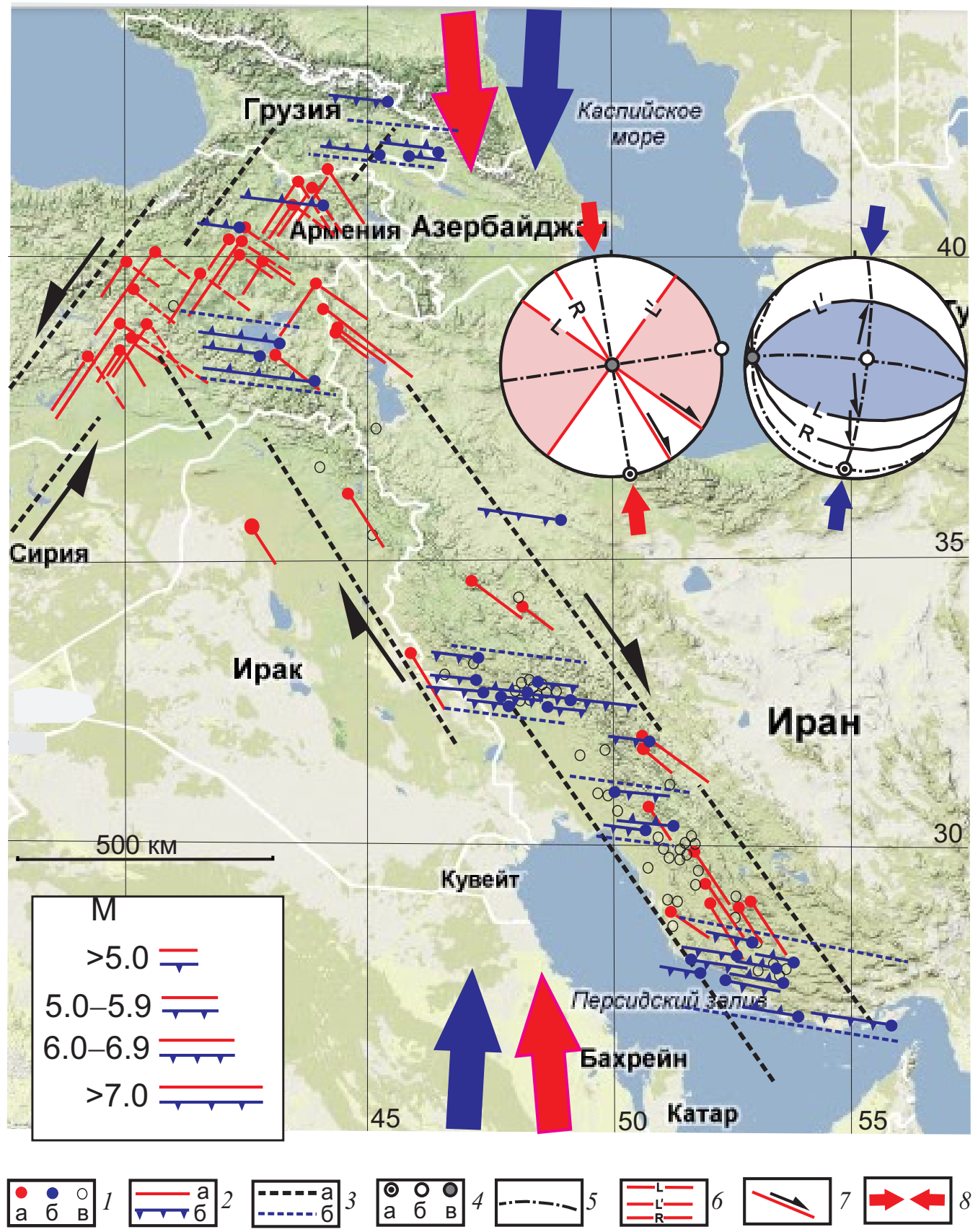

Рис. 4. Стереографические модели сейсмогенеза 1 и 2-го типов (стереограммы) и особенности площадного распределения соответствующих очагов землетрясений (схемы), сформировавшихся в обстановке субмеридионального субгоризонтального сжатия.

На схемах: 1 - очаги землетрясений (а - 1-го типа, б - 2-го типа, в - иных типов); 2 - сейсмогенные разрывы (а - сдвиги, б - взбросы и надвиги, бергштрихи - в направлении падения разрывов); 3 - границы сейсмогенных зон: $a$ - 1-го типа, 6 - 2-го типа; на стереограммах: 4 - проекции главных осей напряжений: максимального (а), минимального (б) сжатия, промежуточной (в); 5 - проекции плоскостей главных осей нормальных напряжений; 6 - проекции плоскостей вероятных сейсмогенных разрывов $\left(L, L^{\prime}, R-\right.$ типы сколов) и их структурно-кинематическая идентификация; 7 - направление перемещения лежачего крыла разрыва; затенены - квадранты растяжения; 8 направление регионального сжатия. Здесь и далее - все построения на нижней полусфере. Врезка в левом нижнем углу - магнитуды землетрясений.

Fig. 4. Stereographic models of Type 1 and Type 2 seismogenesis (stereograms), and specific features of spatial distribution of corresponding earthquake foci (schemes) which formed under submeridional subhorizontal compression.

Schemes: 1 - earthquake foci (a - Type 1, б - Type 2, в - other types); 2 - seismogenic faults (a - shear faults, 6 - thrusts and overthrusts, hachure - direction of fault dip); 3 - boundaries of seismogenic zones: $a$-Type 1, $\sigma$ - Type 2; stereograms: 4 - projections of major stress axes: maximum (а), minimum (б) compression, intermediate (в); 5 - projections of major normal stress axes; 6 - projections of planes of inferred seismogenic faults $\left(L, L^{\prime}, R\right.$ - types of shear) and their structural and kinematical indicators; 7 - displacement direction of the lying wing of the fault; quadrants of extension are shaded; 8 - direction of regional compression. All the reconstructions are done in the lower hemisphere (the same refers to the figures below). The insert in the bottom left corner - magnitudes of earthquakes. 


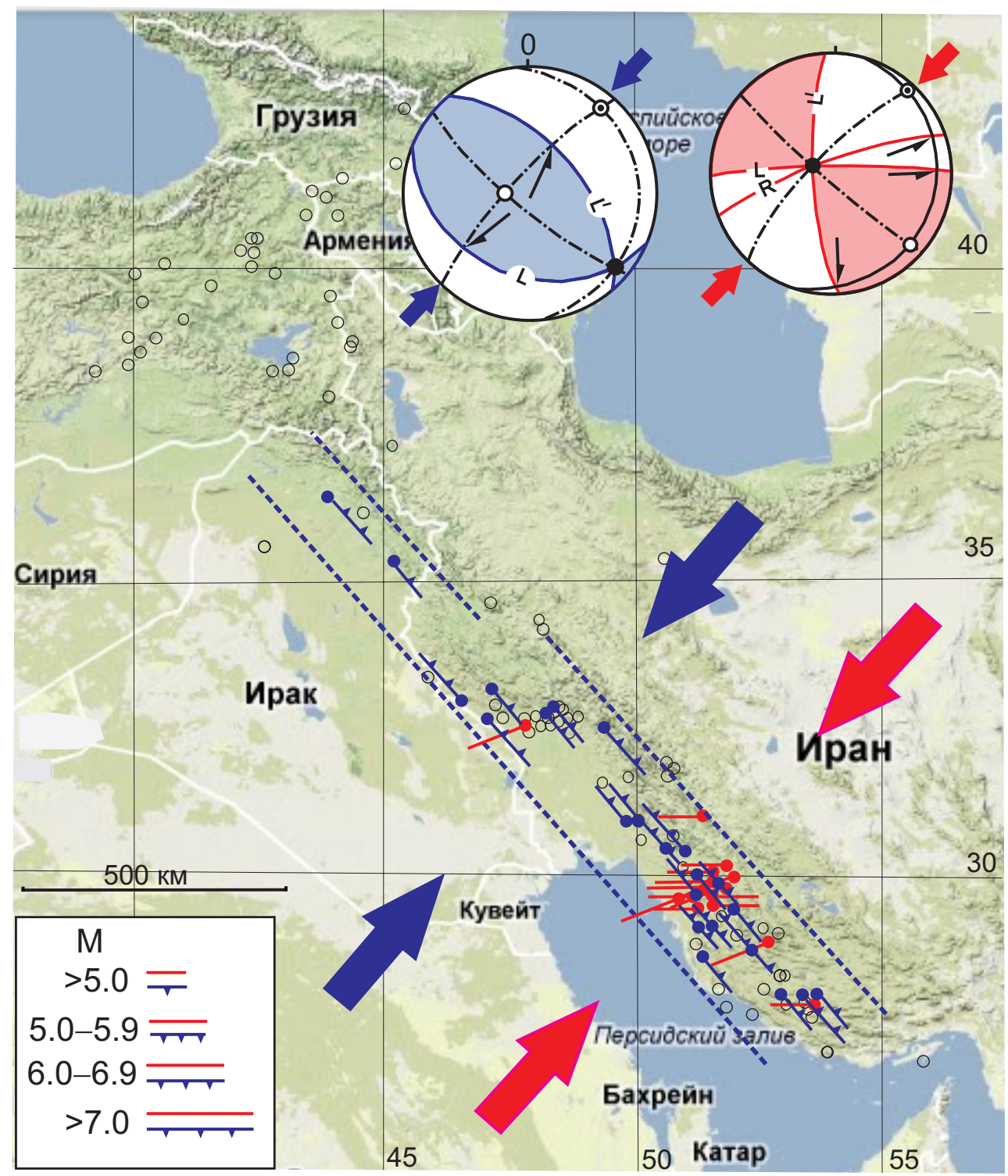

Рис. 5. Стереографические модели сейсмогенеза 3 и 4-го типов (стереограммы) и особенности площадного распределения соответствующих очагов землетрясений (схемы), сформировавшихся в обстановке СВ-ЮЗ субгоризонтального сжатия.

На схемах: кружки - очаги землетрясений (синие - 3-го типа, красные - 4-го типа, незалитые - иных типов). Остальные условные обозначения на рис. 4.

Fig. 5. Stereographic models of Type 3 and Type 4 seismogenesis (stereograms), and specific features of spatial distribution of corresponding earthquake foci (schemes) which formed under NE-SW subhorizontal compression.

In the schemes, circles show earthquake foci (blue - Type 3, red - Type 4, white - other types). See also the legend for Fig.4.

- взбросовый (рис. 5); КМТ - 26 очагов; деформационный режим - взбросовый;

4-й тип: СПМТ - 13 очагов; деформационные режимы - сдвиговый, взбросо- и сбросо-сдвиговый (рис. 5); КМТ - 15 очагов; деформационный режим сдвиговый.

ЮВ-СЗ субгоризонтальное сжатие:

5-й тип: СПМТ - 4 очага; деформационный режим сдвиговый (рис. 5); КМТ - 12 очагов; деформационный режим - сдвиговый.

\section{5. ОСОБЕННОСТИ ПРОЯВЛЕНИЯ СЕЙСМОГЕНЕЗА 1-ГО И 2-ГО ТИПА}

Стереографическая модель сейсмогенеза 1-го типа представлена сейсмогенными разрывами в виде крутопадающих правых сдвигов типа $L-$ и $R$-сколов с простираниями, соответственно, $305^{\circ}$ и $328^{\circ}$, а также $L^{\prime}$-сколов с простиранием 35-40 (см. рис. 4). Ориентировки главных осей напряжений реконструированного регионального поля составляют: $\mathrm{P}=172 \angle 2^{\circ}$ и 
$\mathrm{T}=82 \angle 3^{\circ}$ (нижняя полусфера). Реализация второй нодальной плоскости ( $L^{\prime}$-скола) как левого сдвига не противоречит полученному тензору напряжений и вполне очевидна, особенно на СЗ фланге системы Загрос - в области ее пересечения с зоной ВосточноАнатолийского разлома СВ простирания.

Очаги землетрясений 1-го типа локализованы (хоть и неравномерно) вдоль внешней части СВ фланга Аравийского Синтаксиса, образуя протяженную (более 2000 км) правосдвиговую сейсмогенную зону СЗ простирания. Разрывы в этих очагах представлены преимущественно $R$-сколами, в меньшей мере проявлены $L$-сколы. Почти такое же количество очагов 1-го типа расположено, как уже отмечалось, в области сочленения системы Загрос с зонами Анатолийских разломов.

Выборка землетрясений 1-го типа содержит наибольшее количество (шесть) катастрофических событий с $M \geq 6.0$, вызвавших разрушения зданий и сооружений и повлекших многочисленные человеческие жертвы. Часть этих землетрясений локализована в области сочленения системы Загрос с зоной ВосточноАнатолийского разлома: 24.11.1976 г. $\quad(M=6.1)$, 30.10.1983 г. $(M=6.9), 08.03 .2010$ г. $(M=6.1)$. По кинематическим характеристикам механизмов очагов и особенностям их местоположения сейсмогенный разрыв первого из них идентифицируется как $L$-скол общезагросского простирания. В двух других очагах равновероятно возникновение как $L$-сколов С3 простирания, так и $L^{\prime}$-сколов СВ ориентировки. Три катастрофических землетрясения - 03.05.1989 г. $(M=6.2)$, 01.03.1994 г. $(M=6.0), 06.05 .1999$ г. $(M=6.3)$ - произошли на ЮВ фланге системы Загрос, при этом параметры сейсмогенных разрывов в очагах позволяют идентифицировать их как $R$-сколы общезагросского С3 простирания.

Группа взбросовых землетрясений 2-го типа сейсмогенеза аппроксимирована моделью, которая также отражает обстановку субмеридионального субгоризонтального сжатия $\left(\mathrm{P}=186 \angle 8^{\circ}, \mathrm{T}=50 \angle 78^{\circ}, \mathrm{N}=277 \angle 8^{\circ}\right)$, но с субвертикально ориентированной осью Т, чем обусловлено возникновение в очагах субширотных разрывов взбросового типа с южным падением по типу $L$ - и $R$-сколов. $L$-сколы, имеющие более крутой угол падения $\left(193 \angle 54^{\circ}\right)$, характеризуются как взбросы, а более пологие $R$-сколы $\left(202 \angle 28^{\circ}\right)$ - как надвиги на стереограмме (рис. 4). В этой же модели нодальная плоскость с северным падением соответствует положению $L^{\prime}$-сколов, формирование которых в указанных условиях также вполне вероятно.

Указанные очаги локализованы в пределах нескольких относительно узких непротяженных зон субширотной ориентировки, пространственно приуроченных (примыкающих) к сейсмогенной зоне 1-го типа и косопоперечных по отношению к ней (см. рис. 4). Относительно недавно в их пределах произошло три катастрофических события с $M \geq 6.0$ (22.06.2002 г., $M=6.2 ; 27.11 .2005$ г. с $M=6.1$ и самое крупное земле- трясение в Турции за последние годы - 23.11.2011 г., $M=7.1)$, повлекших многочисленные жертвы и разрушения.

\section{6. ОСОБЕННОСТИ ПРОЯВЛЕНИЯ СЕЙСМОГЕНЕЗА 3- И 4-ГО ТИПА.}

Значительная часть землетрясений Загроса, очаги которых характеризуются взбросовыми деформационными режимами, формировалась в условиях Ю3-СВ сжатия (3-й mun). Параметры очагов этого типа образуют вполне компактные скопления на стереограмме (см. рис. 2) и соответствуют одной стереографической модели. Ориентировки реконструированных осей Р и Т модели составляют $39 \angle 12^{\circ}$ и $266 \angle 72^{\circ}$. Одна из вероятных плоскостей сейсмогенного разрыва представляет собой левый сдвиго-надвиг (надвиг с небольшой левосдвиговой составляющей), падающий в юго-западном направлении $\left(205 \angle 31^{\circ}\right)$, вторая идентифицируется как взброс противоположного падения $\left(51 \angle 58^{\circ}\right)$.

Полученной модели удовлетворяют $22 \%$ всех очагов землетрясений. Они локализованы на юго-восточном фланге и в центральной части изучаемой геоструктуры (схема на рис. 5). Так же, как и очаги 1-го типа, землетрясения 3-го типа относительно неравномерно распределены вдоль зоны северо-западного простирания, элементы залегания и структурно-кинематическая характеристика которой определяются по типу нодальных плоскостей, отождествляемых с сейсмогенными разрывами. Хотя простирание обеих плоскостей согласуется с ориентировкой сейсмогенной зоны, в случаях однонаправленных разрывов в очаге наиболее вероятной является активизация взбросов северо-восточного падения, пространственно-кинематические параметры которых соответствуют положению зоны палеосубдукции Аравийской плиты под Евразийский континент. При этом сдвиговая зона Загроса (1-го типа) как бы «подпирает» последнюю со стороны Евразии, ограничивая область распространения взбросовых очагов пределами внутреннего (по отношению к Аравии) северо-восточного края Аравийского синтаксиса.

Из числа землетрясений данного типа только одно характеризуется магнитудой $M=6.0$. Оно локализовано на юго-восточном фланге системы Загрос; сейсмогенный разрыв в очаге идентифицирован как взброс общезагросского простирания с падением на северовосток, что согласуется с пространственно-кинематическими характеристиками остальных очагов этого типа.

Основными элементами модели сейсмогенеза 4-го типа, происходившего в условиях Ю3-СВ сжатия, являются крутопадающие левые сдвиги типа $L$ - и $R$ сколов с простираниями, соответственно, $\approx 90^{\circ}$ и $\approx 70^{\circ}$ (стереограмма на рис. 5). Ориентировка осей региональных полей напряжений составляет: $\mathrm{P}=42 \angle 6^{\circ}$, 
$\mathrm{T}=135 \angle 14^{\circ}$. В этих же условиях возможно образование и правосдвиговых сейсмогенных разрывов меридиональной ориентировки $-L^{\prime}$-сколов. Однако рассматриваемые очаги локализованы в основном в пределах относительно узкой зоны субширотного простирания (схема на рис. 5), поэтому наиболее вероятно, что сейсмогенным разрывам отвечают нодальные плоскости, ориентированные именно в широтном направлении. В количественном отношении $L$ - и $R$-сколы представлены примерно одинаково, однако единственное землетрясение данного типа с магнитудой, превышающей 6.0 (11.08.1988 г., $M=6.1)$, реализовалось по типу левосдвигового $R$-скола.

Усложняющими данную модель сейсмогенеза элементами можно считать единичные землетрясения взбросо-сдвигового типа, сформировавшиеся в условиях Ю3-СВ сжатия, которые отражают локальные трансформации поля напряжений сдвигового типа.

\section{7. ОСОБЕННОСТИ ПРОЯВЛЕНИЯ СЕЙСМОГЕНЕЗА 5-ГО ТИПА}

Землетрясений, возникших при сдвиговом деформационном режиме в условиях ЮВ-СЗ сжатия, немного. Первое из них (13.04.1998 г., $M=4.8 ; \mathrm{P}=136 \angle 14^{\circ}$, $\mathrm{T}=228 \angle 8^{\circ}, \mathrm{N}=345 \angle 74^{\circ}$, деформационный режим сдвиговый), случилось в области сочленения системы Загрос и зон Анатолийских разломов. Относительно недавно произошло еще три землетрясения подобного типа. Два из них (25.03.2004 г., $M=5.0$ и 28.03.2004 г., $M=5.3)$ локализованы в непосредственной близости от очага 13.04.1998 г. и по решениям механизмов являются полным его аналогом: расхождения в их параметрах составляют всего несколько градусов. Это позволило указанные очаги отнести к одному - 5-му типу сейсмогенеза. Параметры его модели составляют: $\mathrm{P}=138 \angle 12^{\circ}, \mathrm{T}=230 \angle 2^{\circ}$; одна из плоскостей ( $L$-скол) представляет собой субвертикальный правый сдвиг широтного простирания, вторая (L'-скол) - субвертикальный левый сдвиг меридиональной ориентировки (на стереограмме рис. 6). Третье землетрясение (точнее, два толчка с $M=6.5$ и $M=6.4$, последовавшие один за другим с интервалом менее 10 минут) произошло 11.08.2012 г. в Северо-Западном Иране к востоку от предыдущих. Оно вызвало сильные разрушения; число жертв среди населения превысило 300 человек, более 2 тыс. человек получили ранения (http://www.ceme. gsras.ru/cgi-bin/info_quake.pl). Решение механизма этого очага ( $\mathrm{P}=308 \angle 24^{\circ}, \mathrm{T}=48 \angle 21^{\circ}$; правый сдвиг широтной ориентировки) также можно считать вполне удовлетворяющим условиям полученной модели сейсмогенеза 5-го типа. По-видимому, во всех этих случаях сейсмогенным разрывам отвечают плоскости широтного простирания, которые можно рассматривать как активизировавшиеся фрагменты Северо-Анатолийского разлома.

\section{8. ОБСУЖДЕНИЕ РЕЗУЛЬТАТОВ И ВЫВОДЫ}

Таким образом, 97 \% имеющихся решений механизмов очагов исследуемой территории можно аппроксимировать пятью стереографическими моделями (рис. 4, 5, 7). Эти модели отражают основные деформационные режимы и кинематические обстановки сейсмогенного разрывообразования в регионе и являются критериями для структурно-кинематической идентификации сейсмогенных разрывов и зон, в пределах которых локализованы очаги определенного типа.

Построенные стереографические модели основных типов сейсмогенеза в пределах системы Загрос характеризуют главным образом две доминирующие кинематические обстановки - субмеридионального и Ю3СВ сжатия, обусловленные геодинамическими особенностями изучаемой территории. Первая из этих обстановок отражает продолжающееся в настоящее время движение Аравийской плиты в северном направлении. При этом пограничные с ней структуры испытывают, в первую очередь, сдвиговые деформации: на западе (система разломов Акаба - Мертвое море) левые сдвиги, на востоке (Загрос) - правые. Возникновение условий ЮЗ-СВ сжатия вызвано процессами дивергенции в пределах Красноморского рифта, вследствие чего Аравийский полуостров перманентно оказывает давление на Евразию в СВ направлении.

Двойственная геодинамическая природа системы Загрос (правосдвиговая и палеосубдукционная взбросо-надвиговая или шарьяжная), нашедшая отражение в палеогеодинамических реконструкциях и геолого-тектонических построениях [Zonenshain et al., 1987; Bazhenov, Burtman, 1990; и др.], подтверждается и характером регионального сейсмогенеза. Проявление указанных обстановок в виде дискретных событий - землетрясений того или иного типа - свидетельствует о том, что рассматриваемая геодинамическая система постоянно находится в состоянии неустойчивого равновесия, подвергаясь сжатию в двух направлениях. Ее современные деформации, в частности сейсмогенные разрывы, как правило, отражают не суммарное воздействие указанных типов региональных полей напряжений как некоего результирующего поля, а поочередное преобладание напряжений одного типа поля над другим. Развертка сейсмических событий во времени (рис. 7) указывает на разный характер сейсмичности, обусловленной субмеридиональным и ЮЗ-СВ сжатием. В первом случае наблюдается относительно равномерное распределение землетрясений во времени и вспышка событий в 1992-1994 гг. Во втором - отчетливо видно затухание событий в 1983-1984 гг. и более мощный всплеск в 1988-1989 гг. Разный характер и смещение во времени между максимумами событий (равное 4-5 годам) подтверждают вывод о различных причинах субмеридионального и ЮЗ-СВ сжатия.

Попарное комбинаторное сочетание сдвиговых и 


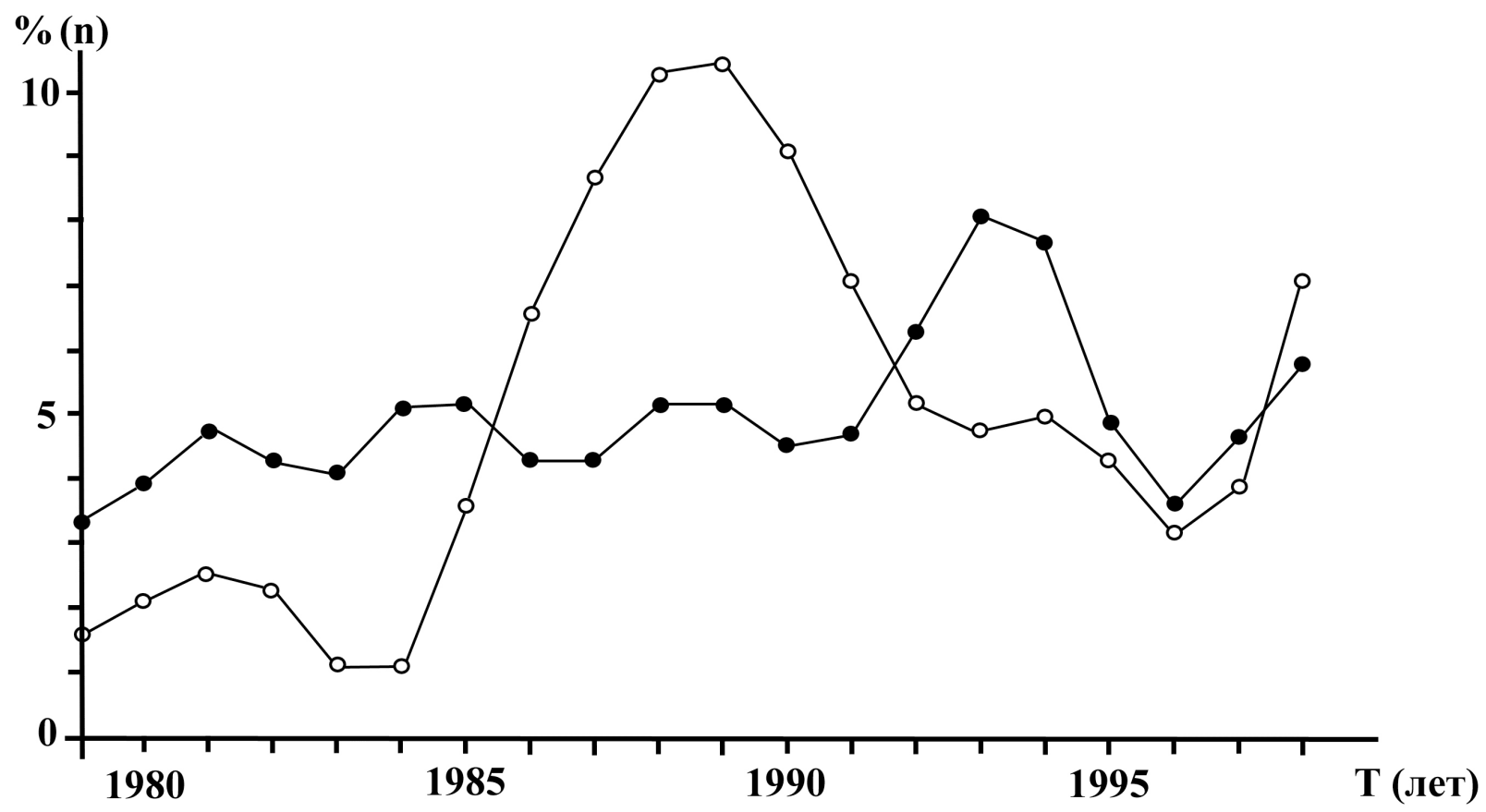

Рис. 6. Временная развертка деформационных режимов субмеридионального (залитые кружки) и ЮЗ-СВ сжатия. Данные, взятые из каталога, сглажены путем осреднения.

Fig. 6. Time range of deformation regimes of submeridional (filled circles) and SW-NE compression. The data from the catalogue are averaged.

взбросовых деформационных режимов при одном направлении сжатия характерно не только для района Загроса, но и для других изученных авторами складчатых систем альпийского пояса - Карпат и Горного Крыма. Сдвиги, как правило, сопровождают все этапы развития складчатой системы - доскладчатый, соскладчатый и послескладчатый, формируясь по краям перемещающихся массивов. Взбросы и надвиги характерны в основном для коротких периодов формирования горного рельефа и возникают также при сжатии уже сформированной горной системы. Складчатая система Загрос имеет преимущественное С3 простирание, поэтому ЮЗ-СВ сжатие должно сопровождаться более выраженным взбросовым деформационным режимом, чем субмеридиональное. Это подтверждается и механизмами очагов землетрясений: в условиях субмеридионального сжатия сдвиговый и взбросовый режимы проявляются в количественном отношении приблизительно одинаково, тогда как в условиях ЮЗ-СВ сжатия взбросовый режим существенно превалирует над сдвиговым.

Анализ пространственного распределения основных типов сейсмогенеза показал, что соответствующие этим типам очаги землетрясений локализованы в пределах зон разной ориентировки и протяженности. Очаги 1-го типа неравномерно распределены вдоль внешней части северо-восточного фланга Аравийского Синтаксиса в виде протяженной правосдвиговой зоны северо-западного простирания, а также в области сочленения системы Загрос с зонами Анатолийских разломов, где равновероятна реализация сейсмогенных разрывов как общезагросского направления, так и отвечающих ориентировкам Восточно- и Северо-Анатолийской зон. Очаги 2-го типа размещены в тех же районах, но субперпендикулярно оси сжатия и косопоперечно по отношению к первым. Взбросовый деформационный режим в этих очагах связан, скорее всего, с тем, что ориентация оси сжатия отличается от предыдущей на $14^{\circ}$ в сторону более крутого угла по отношению к направлению складчатости Загроса. На изученном отрезке времени субмеридиональная ось сжатия, по-видимому, неоднократно изменяла свою ориентировку со $172^{\circ}$ на $186^{\circ}$, так как очаги 1-го и 2-го типа возникали, чередуясь, почти ежегодно (кроме отрезка времени между 1989 и 1992 гг.). Протяженность сейсмогенных зон 2-го типа меньше, и они не выходят за пределы системы Загрос. Вероятно, некоторые из них являются фрагментами зон разломов, секущих эту систему, однако сейсмичность на их флангах проявлена относительно слабо и концентрируется главным образом в пределах самой системы.

Пространственно-кинематические особенности проявлений сейсмогенеза 3-го типа, локализованных вдоль зоны палеосубдукции Аравийской плиты под Евразийский континент, свидетельствуют о периодически продолжающемся в настоящее время поддвиге 


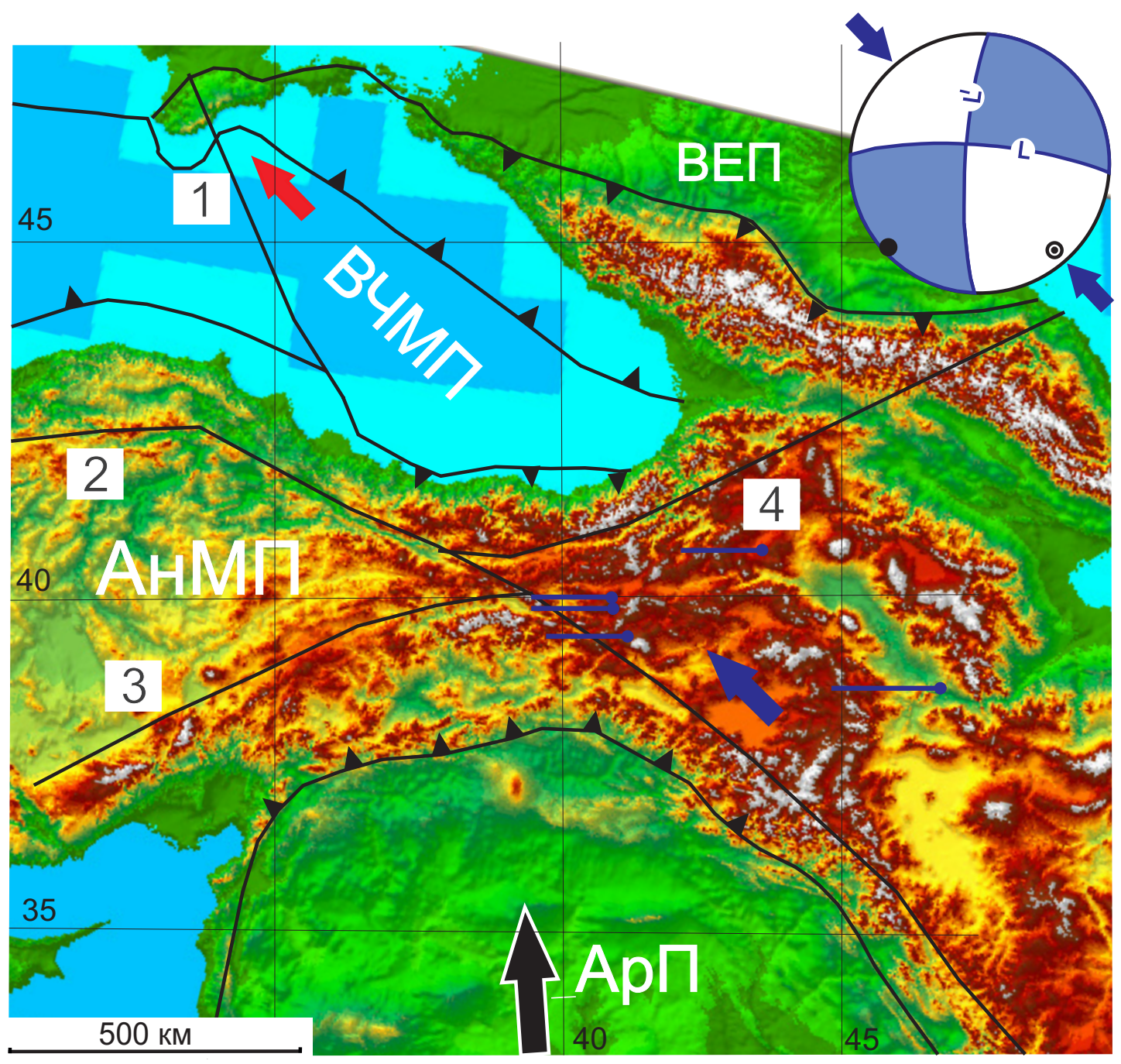

Рис. 7. Карта юго-восточной части Циркумчерноморского региона и стереографическая модель 5-го типа сейсмогенеза.

Зоны разломов (цифры в квадратах): 1 - Центрально-Черноморская, 2 - Северо-Анатолийская, 3 - Восточно-Анатолийская, 4 - Северовосточно-Анатолийская. Плиты и микроплиты (границы показаны контурами с зубцами): АрП - Аравийская, ВЕП - Восточно-Европейская, АнМП - Анатолийская, ВЧМП - Восточно-Черноморская. Стрелки: большая черная - направление движения АрП, средняя синяя - направление давления северной части системы Загрос, малые синие - оси субгоризонтального сжатия в стереографической модели 5-го типа сейсмогенеза, красная - направление нажима ВЧМП на Крымский полуостров.

Fig. 7. The map of the south-eastern part of the Circum Black Sea, and the stereographic model of Type 5 seismogenesis.

Fault zones (numbers in circles): 1 - Central Black Sea, 2 - North Anatolian, 3 - East Anatolian, 4 - North-East Anatolian. Plates and microplates (boundaries are shown by indented contours): АрП - Arabian, ВEП - East European, АнМП - Anatolian, ВЧMП - East Black Sea. Arrows: big black - movement direction of the Arabian plate (АрП), medium-size blue - pressure direction of the Zagros system, small-size blue - axes of subhorizontal compression in the stereographic model of Type 5 seismogenesis, red - direction of pushing of the East Black Sea microplate onto the Crimea peninsula.

первого из этих сегментов тектоносферы под другой. Очаги 4-го типа образуют несколько относительно узких непротяженных зон субширотной ориентировки, пространственно приуроченных к сейсмогенным 30нам 1-го и 3-го типа и косопоперечных по отношению к ним. Таким образом, упорядоченный характер распределения землетрясений разных типов позволяет рассматривать полученные стереографические модели сейсмогенеза в качестве структурно-кинематических моделей соответствующих сейсмогенных зон.
Отметим, что очаги землетрясений, сформировавшихся в условиях субмеридионального сжатия (1-го и 2-го типа), как в количественном выражении, так и с точки зрения их энергетического потенциала, превалируют над очагами иных (3-5-го) типов. Их количество в анализируемой выборке составляет более 68 \%, и именно они характеризуются предельными для изучаемого региона магнитудами: в 10 землетрясениях этих типов значения магнитуд превышают $M=6.0$ (достигая $M=7.1)$, в то время как предельные магнитуды 
очагов 3-го и 4-го типа не превышают величин $M=6.0$ 6.1 и проявляются менее часто (всего два события).

С геодинамической точки зрения интересен 5-й тип сейсмогенеза. Очаги этого типа сосредоточены в самой северной части системы Загрос между $38^{\circ}$ и $40^{\circ}$ с.ш. и не фиксируются в других ее местах. Однако еще севернее - в Горном Крыму и Северном Причерноморье - напряжения ЮВ-СЗ сжатия устанавливаются повсеместно как по тектонофизическим, так и по сейсмологическим данным [Pustovitenko, 2002; Gintov, 2005; Volfman et al., 2012; Murovskaya, 2012] и объясняются давлением Восточно-Черноморской микроплиты на Крым с ЮВ. На рис. 7 видно, что движение Аравийской плиты на север, в сочетании с кинематикой системы Анатолийских зон разломов, создает субширотные секторы растяжения и субмеридиональные секторы сжатия, а в сочетании с формой Восточно-Черноморской микроплиты вызывает давление последней на Кавказский регион в направлении СВ и на Крым в направлении С3. Предполагается также ограниченная субдукция этой микроплиты под Кавказ и некоторое ее поддвигание под Восточный Крым [Volfman et al.,
2004; Gintov, 2005]. Можно утверждать, что установленные сейсмогенные зоны 5-го типа отражают сложную картину взаимодействия северного края Аравийской плиты с окружающими микроплитами.

\section{9. ЗАКЛЮЧЕНИЕ}

Таким образом, предложенная тектонофизическая интерпретация сейсмологических данных (механизмов очагов землетрясений) позволяет дополнить их некоторыми новыми параметрами и сведениями - типами деформационных режимов, направлениями подвижек, более точным выбором «рабочих» нодальных плоскостей, характером связи с известными разрывными структурами - и, главное, представить объективно обобщенную картину региональных полей напряжений, которая отражает направление действия основных тектонических сил в регионе. В конечном итоге это приближает исследователей к познанию истории геодинамического развития Циркумчерноморского региона в целом.

\section{0. ЛИТЕРАTУРA / REFERENCES}

Bazhenov M.L., Burtman V.S., 1990. Structural arcs of the alpine belt: Carpathians - Caucasus - Pamir. Nauka Publishing House, Moscow, 167 p. (in Russian) [Баженов М.Л., Буртман В.С. Структурные дуги альпийского пояса: Карпаты - Кавказ - Памир. М.: Наука, 1990. 167 с.].

Delvaux D., Sperner B., 2003. New aspects of tectonic stress inversion with reference to the TENSOR program. In: Nieuwland D.A. (Ed.) New insights into structural interpretation and modelling. Geological Society, London, Special Publications, V. 212, p. 75-100. http://dx.doi.org/10.1144/GSL.SP.2003.212.01.06.

Gintov O.B., 2005. Field Tectonophysics and Its Using by Studying the Deformations of the Earth's Crust of Ukraine. Fenix Publishing House, Kiev, 572 p. (in Russian) [Гинтов О.Б. Полевая тектонофизика и ее применение при изучении деформаций земной коры Украины. Киев: Феникс, 2005. 572 с.].

Gushchenko O.I., 1973. Analysis of orientations of shear displacements and their tectonophysical interpretation by reconstruction of paleostress fields. Doklady AN SSSR 210 (2), 331-334 (in Russian) [Гущенко О.И. Анализ следов тектонических смещений и их тектонофизическая интерпретация в ходе реконструкции палеонапряжений // Доклады АН СССР. 1973. T. 210. № 2. C. 331-334].

Gushchenko O.I., 1979. The method of kinematic analysis of the fractures in the reconstruction of tectonic stress fields. In: Stress and strain fields in the lithosphere. Nauka Publishing House, Moscow, p. 7-25 (in Russian) [Гущенко О.И. Метод кинематического анализа структур разрушения при реконструкции полей тектонических напряжений // Поля напряжений и деформаций в литосфере. М.: Наука, 1979. С. 7-25].

Gushchenko O.I., Mostryukov A.O., Petrov V.A., 1991. The structure of the regional stress field of the earth crust of the Eastern Mediterranean active belt. Doklady AN SSSR 312 (4), 830-835 (in Russian) [Гущенко О.И., Мострюков А.О., Петров В.А. Структура поля современного регионального напряжения сейсмоактивных зон земной коры восточной части Средиземноморского активного пояса // Доклады АН СССР. 1991. Т. 312. № 4. С. 830-835].

Khain V.E., 2001. Tectonics of Continents and Oceans. Nauchny Mir Publishing House, Moscow, 606 p. (in Russian) [Xauн B.E. Тектоника континентов и океанов (год 2000). М.: Научный мир, 2001. 606 с.].

McKenzie D.P., 1969. The relation between fault plane solutions for earthquakes and the directions of the principal stresses. Bulletin of the Seismological Society of America 59 (2), 591-602.

Murovskaya A.V., 2012. Stress-strained state of the Western Mountain Crimea in Oligocene-Quaternary according to tectonophysical data. Geophysical Journal 34 (2), 109-119 (in Russian) [Муровская А.В. Напряженно-деформированное состояние Западного Горного Крыма в олигоцен-четвертичное время по тектонофизическим данным // Геофизический журнал. 2012. Т. 34. № 2. С. 109-119].

Novik N.N., Volfman Y.M., 1997. Evolution of planetary stress fields within seismically active regions of Ukraine, the latest breaks and discontinuous shift. In: Geodynamics Crimean Black Sea region. Simferopol, p. 81-90 (in Russian) [Новик Н.Н., Вольфман Ю.М. Эволюция планетарных полей напряжений в пределах сейсмоактивных регионов Украины, новейшие разрывы и разрывные смещения // Геодинамика Крымско-Черноморского региона. Симферополь, 1997. С. 81-90]. 
Pustovitenko B.G., 2002. Mechanisms of sensible earthquakes of Crimea-Black Sea region during last 20 years. In: Seismological Bulletin of Ukraine for 2000 ${ }^{\text {th }}$. IG NANU, KES, Sevastopol, p. 59-64 (in Russian). [Пустовитенко Б.Г. Механизм очагов ощутимых землетрясений Крымско-Черноморского региона последних 20 лет // Сейсмологический бюллетень Украины за 2000 год. Севастополь: НПЦ «ЭКОСИ-Гидрофизика», 2002. С. 59-64].

Rebetsky Y.L., 2003. Stress-strained state and mechanical properties of natural massifs according to the mechanisms of earthquake centres and structural-kinematic characteristics of cracks. Synopsis of PhD Thesis (Candidate of Physics and Mathematics), Moscow, 54 p. (in Russian) [Ребецкий Ю.Л. Напряженно-деформированное состояние и механические свойства природных массивов по данным о механизмах очагов землетрясений и структурно-кинематическим характеристикам трещин: Автореф. дис. ... докт. физ.-мат. наук. М.: ОИФЗ, 2003. 54 с.].

Rebetsky Y.L., 2005. Evaluation of the relative stress values - the second stage of reconstruction according to discontinuous shifts data. Geophysical Journal 27 (1), 20-38 (in Russian) [Ребецкий Ю.Л. Оценка относительных величин напряжений - второй этап реконструкции по данным о разрывных смещениях // Геофизический журнал. 2005. Т. 27. № 1. C. 20-38].

Sherman S.I., Gintov O.B., Bornyakov S.A., Isai V.M., Kobylyansky V.B., 1988. The nature of faulting in the consolidated crust and modeling of shear zones. Geophysical Journal 10 (1), 13-21 (in Russian) [Шерман С.И., Гинтов О.Б., Борняков С.А., Исай В.М., Кобылянский В.Б. Характер разломообразования в консолидированной коре и моделирование зон скалывания // Геофизический журнал. 1988. Т. 10. № 1. С. 13-21].

Stoyanov S.S., 1977. The mechanism of formation of fault zones. Nedra Publishing House, Moscow, 144 p. (in Russian) [Стоянов С.С. Механизм формирования разрывных зон. М.: Недра, 1977. 144 с.].

Volfman Y.M., 2013. Structural and kinematic identification of seismogenic zones of the Zagros system (according to mechanisms decisions of earthquake centres). Geophysical Journal 35 (2), 38-64 (in Russian) [Вольфман Ю.М. Структурнокинематическая идентификация сейсмогенных зон системы Загроса (по данным решений механизмов очагов землетрясений) // Геофизический журнал. 2013. Т. 35. № 2. С. 38-64].

Volfman Y.M., Gintov O.B., Ostanin A.M., Kolesnikova E.Y., Lazarenko O.E., Pryadun M.L., 2004. Peculiarities of tectonophysical interpretation of thrust structures of the South-western and Eastern Crimea. In: Proceedings of the 8-th International Scientific and Practical Conference "Oil and Gas of Ukraine 2004", V. 1. Kiev, p. 57-58 (in Russian) [Вольфман Ю.М., Гинтов О.Б., Останин А.М., Колесникова Е.Я., Лазаренко О.Е., Прядун М.Л. Особенности тектонофизической интерпретации надвиговых структур Юго-Западного и Восточного Крыма // Материалы 8-й Международной научно-практической конференции «Нефть и газ Украины - 2004». Т. 1. Київ, 2004. С. 57-58].

Volfman Y.M., Kolesnikova E.Y., Pustovitenko A.A., 2012. Kinematic conditions of tectonic faulting and seismicity in the Crimean region. In: Seismology and geophysical studies in the seismic regions. Proceedings of the conference-seminar. “Spolom” Publishing House, L`viv, p. 33-36 (in Russian) [Вольфман Ю.М., Колесникова Е.Я., Пустовитенко А.А. Кинематические обстановки тектонического разрывообразования и сейсмичности в Крымском регионе // Сейсмологічні та геофізичні дослідження в сейсмоактивних регіонах: Матеріали наукової конференції-семінару. Львів: В-во «СПОЛОМ», 2012. С. 33-36].

Vvedenskaya A.V., 1969. Study of stresses and displacements in earthquake centres using the theory of dislocations. Nauka Publishing House, Moscow, 136 p. (in Russian) [Введенская А.В. Исследования напряжений и разрывов в очагах землетрясений при помощи теории дислокаций. М.: Наука, 1969. 136 с.].

Yunga S.L., 1996. Seismotectonic deformation of the Northern Eurasian fold belts in the neotectonic phase. Izvestiya, Physics of the Solid Earth 32 (12), 955-974.

Zonenshain L.P., Derkur J., Kazmin V.G., Rick L.-E., Knipper A.L., Le Pichon K., Sbortshikov I.M., Grandzhake S., Pechersky M.D., Zheyssan J., Lepvrier S., Savostin L.A., Sorokhtin O.G., Boelen J., Sibue J.-C., Bazhenov M.L., Westphal M.V., Lauer J.P., Biju-Duval B., 1987. The evolution of the Tethys. In: Story of the Tethys. Institute of Geological Sciences of AS of the USSR, Moscow, p. 104-115 (in Russian) [Зоненшайн Л.П. , Деркур Ж., Казьмин В.Г., Рику Л.-Э., Книппер А.Л., Ле Пишон К., Сборщиков И.М., Гранджаке С., Печерский Д.М., Жейссан Ж., Лепвриер С., Савостин Л.А., Сорохтин О.Г., Булен Ж., Сибуэ Ж.-К., Баженов М.Л., Вестфаль М.В., Лауэр Ж.П., Бижу-Дюваль Б. Эволюция Тетиса // История океана Тетис. М.: Институт геологических наук АН СССР, 1987. С. 104-115].

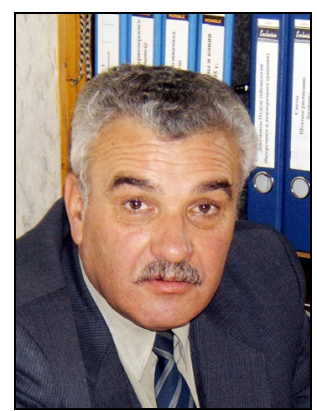

Вольфман Юрий Михайлович, канд. геол.-мин. наук, с.н.с., заведующий отделом сейсмологии Институт геофизики им. С.И. Субботина НАН Украины

Тел.: +38(0652)620537, +38(050)1905404; \ e-mail: seism.volf@gmail.com

Volfman, Yuriy M., Candidate of Geology and Mineralogy, Senior Researcher, Head of the Seismology Division S.I. Subbotin Institute of Geophysics, National Academy of Sciences of Ukraine

Tel.: +38(0652)620537, +38(050)1905404; $\bowtie$ e-mail: seism.volf@gmail.com 


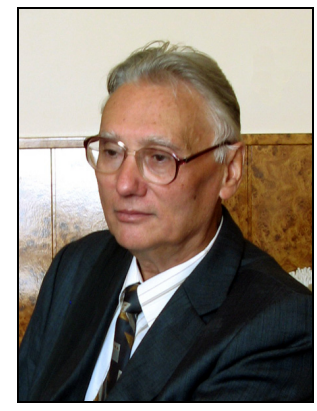

Гинтов Олег Борисович, член-корреспондент НАН Украины, докт. геол.-мин. наук, профессор,

г.н.с. отдела тектонофизики

Институт геофизики им. С.И. Субботина НАН Украины

Тел.: +38(044)4240300; моб. +38(097)1720971; e-mail: oleg.gintov@gmail.com

Gintov, Oleg B., Corresponding Member of NAS of Ukraine, Doctor of Geology and Mineralogy, professor, Chief Researcher of Division of Tectonophysics

S.I. Subbotin Institute of Geophysics, National Academy of Sciences of Ukraine

Tel.: +38(044)4240300; mobile+38(097)1720971; e-mail: oleg.gintov@gmail.com

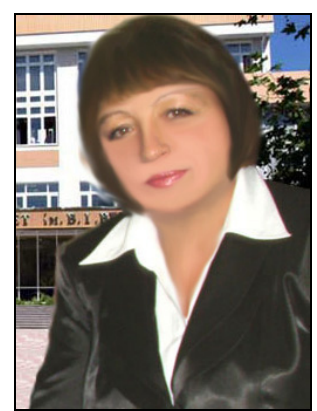

Колесникова Екатерина Яковлевна, инженер отдела сейсмологии

Институт геофизики им. С.И. Субботина НАН Украины

Тел.: +38(0652)620537; e-mail: seism.volf@gmail.com

Kolesnikova, Ekaterina Ya., Engineer, the Seismology Division

S.I. Subbotin Institute of Geophysics, National Academy of Sciences of Ukraine

Tel.: +38(0652)620537; e-mail: seism.volf@gmail.com

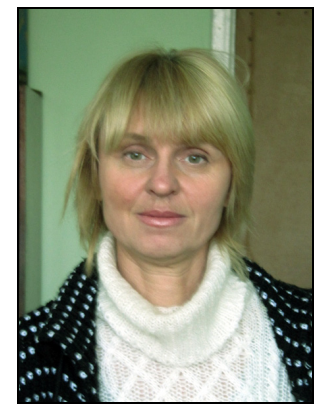

Муровская Анна Валериевна, канд. геол.-мин. наук, м.н.с. отдела тектонофизики

Институт геофизики им. С.И. Субботина НАН Украины

Тел.: +38(044)4240300, моб. +38(098)5238820; e-mail: murovskaya@gmail.com

Murovskaya, Anna V., Candidate of Geology, Junior Researcher of Division of Tectonophysics

S.I. Subbotin Institute of Geophysics, National Academy of Sciences of Ukraine

Tel.: +38(044)4240300, mobile +38(098)5238820; e-mail: murovskaya@gmail.com 